\title{
O travo amargo da história GABRIEL COHN
}

C ONVENHAMOS. Um manifesto não pode durar 150 anos. Há algo de errado nisso. Mas não é nele e sim no curso do mundo que se encontram as razões dessa teimosa persistência. Seus autores não se propunham mais, nem menos, do que um texto de ocasião: na ocasiāo da mudança do mundo. Estranho destino, o de Marx e Engels. $O$ manifesto que redigiram quando jovens é lido um século e meio depois como se fosse obra científica, a ser testada pela acuidade das análises e pela validade das suas previsóes. E a obra que apresentaram ao mundo como sendo do mais alto rigor científico, a sua crítica da economia política, ainda é lida por muitos como se fora um manifesto.

O Manifesto Comunista é o documento constitutivo de uma classe, para a qual até inventa o nome. E o anúncio do nascimento de uma nova entidade histórica (vale dizer, capaz de fazer história). Ao fazê-lo, presta homenagem, na figura da burguesia, à classe que inadvertidamente preparou o cenário para esse advento. Pois é de um advento que se trata. Visto por este ângulo o Manifesto é a expressão mais plena da secularização do messianismo. Despojado da fé religiosa e das ilusóes, dedica-se a introduzir uma dimensão nova na concepçáo de história e de política: a da responsabilidade histórica coletiva. Cumpre à nova classe pôr-se à altura do seu momento e converter-se em sujeito racional. Há uma interpelação no Manifesto, mais do que um anúncio ou uma celebração. Neste texto em que ética e política se entrelaçam sem recorrer a quaisquer apoios externos, a nova classe é conclamada a provar sua condição de sujeito, pela capacidade de conscientemente dar início ao novo. Está em causa uma responsabilidade sem qualquer pacto prévio que lhe dê legitimidade ou apoio; seja o pacto com Deus, seja o contrato social constitutivo da sociedade civil profana. Todos os grandes temas de um pensamento que desembocara na razão ilustrada encontram guarida no registro turbulento e alegre deste radical texto de juventude, em que jovens intelectuais falam da jovem classe.

A referência do Manifesto é a uma classe que se quer universal e tem condiçôes para tanto. $O$ ato de gênio de Marx e Engels consiste em perceber que, na perspectiva da história, o advento de uma classe social náo é o mero acréscimo de uma categoria classificatória, nem se reduz a um passo entre outros de um processo de diferenciação daquilo que antes só era mais simples. A 
nova classe, ao constituir-se (vale dizer, ao ganhar condiçóes para organizar-se politicamente por suas próprias forças) rompe a continuidade histórica e the imprime nova forma. Desde que seja capaz de organizar-se pelas próprias forças, claro. Do contrário, outros falarão por ela. E é exatamente isso que Marx e Engels queriam evitar; daí o tom ansioso do seu texto. A uniáo da classe é a marca da sua organização particular. Mas, ao ocorrer, confere-lhe essa dimensão universal que fecha o círculo da argumentaçáo do Manifesto. Historicamente o proletariado teria tudo (por não ter nada, salvo os grilhóes) para alcançar o inteiramente novo: o particular que, a unir o seu poder ao seu querer e converter-se em universal, realiza, numa nova dimensão, aquilo que a classe anterior preparou. E o legado da burguesia não é de pouca monta, nem o é a tarefa de alçá-lo em nível mais elevado. Têm razão os que enfatizam o crédito positivo que o Manifesto lhe reserva, embora em geral náo percebam o papel que esse reconhecimento desempenha no texto.

Não por acaso Marx e Engels sempre desconfiaram dos dispositivos de representaçáo política. É que toda a sua atençáo está voltada para a capacidade de uma classe de fazer o que lhe cabe por suas próprias forças. A sua tarefa consiste em realizar na sua plenitude histórica a grande exigência que fascinava e embaraçava o idealismo alemão: a autonomia.

Mas, um legado é um legado. $\mathrm{E}$ isto vale para as aquisiçōes históricas da burguesia tanto como, no seu registro próprio, para o Manifesto Comunista. Quando não levado adiante por seus legítimos herdeiros ele se converte em objeto de disputas estéreis e de degradação. E se os herdeiros não chegarem a falar por sua própria voz outros falaráo por eles. E a heteronomia se instalará no coração mesmo do processo histórico: no ponto de onde deveria ter sido expulsa, segundo o Manifesto. Textos alegres de juventude que cobram sem culpa e sem concessóes aquilo que depois se revelou impossível só podem ser relidos com um travo amargo. Enquanto isso o mundo segue seu curso e prepara novas juventudes, talvez mais felizes.

Gabriel Cobn é professor do Departamento de Ciência Política da FFLCH-USP e editor da revista Lua Nova, do Centro de Estudos de Cultura Contemporânea (Cedec). 